\title{
Financial Inclusion: Exploring the Potentials of Daily Savings Enterprises (DSEs) in Savings Mobilization and Credit Delivery in Cross River State, Nigeria
}

\author{
Innocent Asuquo Asuquo* Eno Donatus Uwah \\ Department of Agricultural Economics, University of Calabar, Calabar - Nigeria
}

\begin{abstract}
The study examined the potentials of Daily Savings Enterprises (DSEs) in savings mobilization and credit delivery as a veritable tool in financial inclusion of low income groups in Cross River State. A total of 60 DSEs and 99 member-savers were randomly selected for the study. Data was analyzed using multiple regression. Data analysis from the savings function showed that the number of member-savers per DSE and income of the participants were significant, while the credit delivery function revealed that number of member-savers, volume of savings in a year, interest charged and volume of credit already extended were significant, and key variables in credit delivery. Arising from this, therefore, the study recommends the inclusion of DSEs in the National Financial Inclusion Strategic Plan for a robust mobilization of the low income groups in Nigeria.
\end{abstract}

Keywords: DSEs, Savings, Credit delivery, National Financial Inclusion.

DOI: $10.7176 / \mathrm{JBAH} / 11-12-03$

Publication date:June $30^{\text {th }} 2021$

\section{Introduction}

In many developed and developing economies, finance is a critical element for industrial development. Studies by Berger and Udell (2004) and Isong (2010) showed the consequences of limited access to financial resources on a country's growth and development. While finance obviously may not be the only problem militating against the development of firms, it is certainly the most formidable (Ijere 1986). Firms depend on a variety of financial resources, both internal and external, to finance production. However, internal and external funds in whatever form are built from savings, and theories of Investments (Profit theory, the accelerator theory and financial theory), further emphasize the importance of savings in terms of capital stock and undistributed earnings. Invariably, savings is very key in investment decisions and productivity of any nation.

It is consequent upon this that government at different levels and at various times in Nigeria have emphasized savings and have implemented different savings and credit schemes which are always targeted at addressing financial constraints. Ironically, in spite of government's efforts, many business owners and potential borrowers still have difficulties accessing funds particularly from formal financial institutions. Graham (1992) and Yaron (1992) observed that, many of these schemes failed because government efforts and energies were devoted to mostly supply-led financial development strategies. In other words, the financial institutions through which credit was channeled to borrowers were faulty in design; and were not true financial intermediaries and as a result; were incapable of mobilizing deposits. Arising from this, therefore, these institutions were constraint and inefficient and ended up with loans that were not serviced. The problem of mobilizing savings was not just specific to government credit schemes, conventional banks that were not part of the schemes equally had issues mobilizing deposits and extending credit; and according to Adeyemo and Bamire (2005) many low income Nigerians were affected by this problem, particularly with regards to credit, and these Nigerians constitute more than $80 \%$ of the overall population. It has been observed by Iganiga and Asemota (2008) that the exclusion of this group and this majority is the reason for the slow industrial growth in the country. The formation of many groups with the sole aim of tackling many economic challenges arose from this exclusion. Many had to create alternatives to building financial resources and most importantly at solving their credit needs. The proliferation of Daily Saving Enterprises (DSEs) in many parts of the country, though in existence before now, became even a powerful tool to many low income persons. The DSEs somehow filled the void created by formal institutions as farmers, market men and women, other businesses, and public servants, had their versions and were active participants in savings mobilization and credit extension. The situation today is not significantly different. DSEs still exist in many rural and urban centers and have been termed by many as "the modern unorganized mobile banking scheme", with a banker (money collector) and his clients (savers). The dynamic role of DSEs has been acknowledged and recognized with many noting that if properly harnessed, has huge potentials for sustainable economic development. Iganiga and Asemota (2008) for instance, see DSEs as engines through which growth and economic development can be achieved.

The Launch of the National Financial Inclusion Strategy (NFIS) in 2012 was to reduce the adult financial exclusion rate from $46.3 \%$ in 2010 to $20 \%$ by 2020 (Akin-Fedeyi and Prochazka 2016). The six facets of the strategy were savings, affordable credit, insurance, payment and remittances, financial advice and bank accounts. 
The launched of NFIS was for vulnerable and low income groups who are excluded by conventional banks but are active participants in DSEs. It was revealed that key barriers to financial inclusion was long distance to financial access points, lack of income, lack of financial literacy and trust in financial sector, high cost of financial services, and cumbersome documentation requirements (EFInA, 2010). As at 2014, the percentage of adult population that were financially included in terms of savings and credit in the formal financial sector were $32 \%$ and $3 \%$, respectively. Again, as at $2014,16.7 \%$ of the adult population or 15.6 million adults had savings with informal institutions such as DSEs, cooperatives, etc. $20.8 \%$ or 19.4 million saved with friends, family or at home. In terms of credit, $92 \%$ of micro entrepreneurs, of which $24 \%$ were small and medium enterprises had no access or were financially excluded. It has been observed that in achieving a comprehensive financial inclusion, the first step is to achieve credit inclusion for the disadvantaged and the vulnerable sections of the society. Nevertheless, Akin-Fedeyi and Prochazka (2016) were of the view that targeting a segment of the society and particularly individuals who saved with informal groups was important to achieving formal financial inclusion but, financial services providers should build linkage models with those informal savings institutions to exploit this sizeable market potential. In doing this, agent banking, which is the core practice of DSEs, and mobile money, are two channels through which more frequent contributions (Savings) may be achieved in a costeffective manner. Therefore, to drive financial inclusion successfully, financial services providers should form partnerships with informal savings institutions (DSEs), promote and adopt agent banking and mobile money, given their potentials of bringing financial services to remote areas at substantially lower cost. It is consequent on this linkage benefits that this study was focused on;

$\Rightarrow$ Identifying the operators and clienteles of DSEs in Cross River State.

$\Rightarrow$ Examining the determinants of savings and credit extension in DSEs and implications for National Financial Inclusion Strategy.

$\Rightarrow$ Determining the volume of credit extended in the last one year.

$\Rightarrow$ Assessing the challenges in DSEs operations and means of overcoming them.

\section{Literature review}

The theoretical underpinnings of savings as drivers of economic growth are well documented and diverse .Okoroji and Bose(2011) were of the view that savings is crucial in a growing economy because it influences the level of economic activities, as money saved is ploughed back into the system for investments. Economists such as Keynes, Friedman and Duesenberry, are in agreement that savings build wealth. While some differences may be noted in these views, the centre-piece however, is that, savings leads to investments and investment to economic growth. DSEs are observed by many as key drivers of the economy as their activities are tilted towards capital accumulation, which is a prime factor in economic growth (Iganiga and Asemota 1998; Ike and Idoge 2006, Akanji, 2010).

In assessing the operators and operations of DSEs, Iganiga (2000) reported that the operators were mostly unemployed men and women, or retired government workers, who were either married or single, and their clients cut across traders of all kinds of wares, low ranked staff of government ministries and married women. A well-designed card with date, amount received, depositor's name and permanent address, collector's name and address, with a space for a passport-size photograph as well as what should be the weekly charge by the collector, is required by an operator. A notebook is used as a back-up to record the transactions as well. The card is design such that all the days in a particular month are captured. The operator or the mobile banker, in all ramifications, must be someone that the identity is not in doubt; a familiar entity who knows the environment well enough. A common characteristic of most DSEs is that, participants are usually drawn from the neighbourhood on the basis of common interest such as religion, social status and business arrangements.

Participants of DSEs are majorly people in the low income group. Iganiga (2000) observed that, the disposable income (income level) influence the volume of savings. Apart from income level, 90\% of DSEs are built on trust (Uneze 2013). Trust and operator's confidence are essential to getting these participants to save. While interest on savings may sway participants to deposit with one DSE or another and may not necessarily influenced their savings habits, it is however, a key determinant in credit demand. Many would-be savers assess the potential to access loan from an operator and the interest thereof before participating. In terms of credit supply, operators are significantly influenced by years of membership and reliability of participants. According to Udoh (2005) participants' type of business and profit additionally determines what an individual gets as credit. Many researchers (Iganiga and Asemota 2008; Bime 2010; Akanji 2010), are of the view that trust guides the operation of DSEs in many parts of the country as the demand for collateral is not a pre-condition. Invariably, trust is very key not just to operators who extend credit but to participants who save with these operators. While noting the impact of DSEs in credit delivery to the urban and rural poor, Idowu et al (2011) opined that, formal credit delivery and financial services to the poor in developing economies have failed because the needs of this category of persons are usually not served; arising from high risk and high transaction costs associated with small loans and savings. Consequently, the study concludes that if DSEs growth strategy is adopted and the 
latent entrepreneurial capabilities of the large segment of the urban and rural poor is sufficiently stimulated and sustained, the multiplier effect will be felt in the economy.

DSEs are known to concentrate on short-term financing owing to high demand for loans with limited financial base. That is, liquidity is a factor of the credit supply base of the DSEs. It is observed that savings mobilized depends on the number of participants but, even at that, the liquidity may not be sufficient to cater for all loans demand. Consequently, few participants are served at a time and on short-term duration, ranging from a month to about three months (Eboh 2000). It is only in very rare cases that the loan duration may extend to six months (Udoh 2005).

To mobilized savings on a daily basis, many operators cover at least a distance of 10 kilometers. This challenge may affect smooth mobilization particularly for operators without means of transportation. Therefore, trust issues, enough liquidity for credit demand and mismanagement of funds are major challenges of DSEs. Microfinance activities as displayed by DSEs come in many shapes; from savings and credit delivery, to social intermediation, however; access to credit in form of short-term small-scale has the potential of reaching many urban and rural areas to a greater extent than any macroeconomic development strategy by government and formal financial institutions ( Mejeha et al 2007; Adjei et al 2009). Today, just as in time past, business start-ups in advanced and developing countries depend predominantly on savings and informal credit as major determinants of agricultural production scale, adoption of technology and general expansion of the economy. Harnessing this level of credit therefore, is key to

\section{Materials and methods}

Study area:

The study area is Cross River State, which is in south-south geo-political zone of Nigeria. It is located on latitude $4^{0} 28^{\prime} \mathrm{N}$ and $6^{0} 55^{\circ} \mathrm{N}$ and longitude $7^{0} 50^{\circ} \mathrm{E}$ and $9^{0} 28^{\circ} \mathrm{E}$ of the Greenwich meridian. Cross River State is one of the 36 states in Nigeria, covering a land area of $22,342.176 \mathrm{sq} . \mathrm{km}$, with annual rainfall range of $2942 \mathrm{~mm}$ to $3424 \mathrm{~mm}$. Since it's located in tropical rainforest belt of Nigeria, crops such as rubber, cocoa, oil palm, cassava, plantain, etc. are cultivated. Livestock and fish production are also widely practiced. The State's population as at 2006 was 2.89 million and was projected to be 3.8million in 2016 based on annual growth rate of $2.99 \%$ (National Population Commission of Nigeria 2017). Majority Cross Riverians (75\%) are into small-scale farming businesses; but combine farming with other businesses to make ends meet. Hence, instances are recorded were farmers may be selling articles that are not farm related. Others are in the public service sector.

Sampling technique and data collection

Cross-sectional survey data was collected from three agricultural zones in the state. The zones are Calabar, Ikom and Ogoja. Each of this zone has at least five (5) local government areas each. Twenty (20) DSEs were purposively sampled from each zone, making a total of sixty (60) DSEs. A structured questionnaire with information on savings and credit procedure of DSEs was administered on the Operators and member savers. Since member-savers in the sixty (60 DSEs were over eleven thousand, a sample size of 99 using error margin of $\pm 10 \%$ was used in selecting the respondents for the study from the population. Selected students and agricultural extension agents were used in administering the instruments of data collection.

Data analysis

Descriptive statistics such as frequency distribution, mean, elasticity and percentages were used to analyze savings behavior of sampled respondents, volume of credit extended to participants, and challenges faced by the DSEs Multiple regression analytical technique was used to analyzed factors of savings behaviour and credit extended to participants.

The savings function is given as:

$\mathrm{Y}=\alpha_{0}+\alpha_{1} \mathrm{k}_{1}+\alpha_{2} \mathrm{k}_{2}+\alpha_{3} \mathrm{k}_{3}+\mathrm{e}$

Where;

$\mathrm{Y}=$ Volume of savings mobilized in a year (in Naira)

$\mathrm{k}_{1}=$ Number of member savers

$\mathrm{k}_{2}=$ Duration of savings (in Months)

$\mathrm{k}_{3}=$ Income of participants (in Naira daily)

$\mathrm{e}=$ error term

$\alpha_{0}=$ constant

and the credit functions is expressed as:

$\mathrm{CD}=\mathrm{b}_{\mathrm{o}}+\mathrm{b}_{1} \mathrm{x}_{1}+\mathrm{b}_{2} \mathrm{x}_{2}+\mathrm{b}_{3} \mathrm{x}_{3}+\mathrm{b}_{4} \mathrm{x}_{4}+\mathrm{b}_{5} \mathrm{x}_{5}+\mathrm{U}$

Where $\mathrm{CD}=$ credit demanded and delivered

$\mathrm{x}_{1}=$ Number of members-savers

$\mathrm{x}_{2}=$ Duration of savings per participant (in Months)

$\mathrm{x}_{3}=$ Volume of savings received per participant (in Naira)

$\mathrm{x}_{4}=$ Interest amount charged (in Naira / Month) 
$\mathrm{x}_{5}=$ Volume of credit already received

\section{Results and discussion}

\section{Characteristics of operators and clienteles of daily savings enterprises}

The operators of DSEs as revealed by the study are generally women (68.3\%) and most clients or member-savers are also women (72.1\%). The mean ages are 36.4 and 54.11, respectively. Married persons also dominate DSE operations, with $58.4 \%$ of the operators having just a secondary school certificate qualification. However, with $41.7 \%$ having tertiary education and qualification, the study clearly shows that lack of white or blue collar jobs, other than the desire to earn more money may have attracted these ones. According to National Bureau of Statistics (NBS, 2018), 23.1\% of employable Nigerians are without jobs. Like some studies on DSEs (Iganiga 1996; Nweze 2002, Iganiga and Asemota 2008), member-savers are either housewives, traders, retired or serving civil servants and farmers. This study equally showed that DSEs operations in Cross River State are dominated by traders/ petty business men and women $(60.31 \%)$, followed by farmers $(19.98 \%)$ public/civil servants $(10.27)$ and housewives $(9.44 \%)$, respectively.

Eleven thousand, nine hundred and eighty two $(11,982)$ member-savers are registered with sixty $(60)$ DSEs sampled as recorded by the operators. Using error margin of $\pm 10 \%$, ninety-nine (99) of these member-savers opinions were sought on the possible reasons for saving with DSEs in the midst of many banks and other formal financial institutions. No administrative bottlenecks, easy access to credit facility, nearness to business environment and low interest rate for loan amount; were the different reasons adduced for their participation in DSEs. Accordingly, and in order of importance, $92.93 \%, 90.90 \%, 89.90 \%$ and $62.63 \%$ were of the view that, low interest rate, easy credit access, nearness to business place and absence of administrative bottlenecks were advanced as reasons. This, again, emboldens other studies (Adams and Vogel 1986; Eboh 1995; Akanji 1998) on the ever widening informal financial market, which hinges primarily on easy access to credit and absence of administrative red tapism.

Many DSEs operators (63.33\%) give credit to member-savers who have stood the test of time. That is, years of one's participation guarantees the amount of credit given. And in giving such credit, $48.33 \%$ charge between 6-10\% interest rate, with a mean charge of 7.70. This only corroborates Akin-Fadeyi and Prochazka (2016) assertion on why many low-income groups are financially excluded. According to them, one very key reason is the interest charged. Many of these savers will prefer a DSE that charges less than $10 \%$ interest rate on loan amount than a bank that charges $18 \%$. World bank reported the average lending interest rate for Nigeria in 2019 as $17.58 \%$ which is far above the average lending rate of most DSEs $(7.70 \%)$.

Table 1: Summary statistics of operators and clienteles characteristics of daily savings enterprises

\begin{tabular}{lllll}
\hline S/n & Variable & Frequency & Percentage & Mean \\
\hline $\mathbf{1}$ & Sex of operators & $\mathrm{n}=60$ & & \\
& Male & 19 & 31.7 & \\
& Female & 41 & 68.3 & \\
\hline $\mathbf{2}$ & Sex of member-savers & $\mathrm{N}=11,982$ & & \\
& Male & 3,337 & 72.9 & \\
& Female & 8,645 & & \\
\hline $\mathbf{3}$ & Age of operators & $\mathrm{n}=60$ & 3.33 & \\
& $<20$ & 2 & 21.7 & \\
& $21-30$ & 13 & 41.7 & \\
& $31-40$ & 25 & 30 & \\
& $41-50$ & 18 & 3.33 & \\
& $>50$ & 2 & & \\
\hline $\mathbf{4}$ & Age of member-savers & $\mathrm{N}=11,982$ & & \\
& $<20$ & 22 & & \\
& $21-30$ & 746 & & \\
& $31-40$ & 1,101 & & \\
& $41-50$ & 1465 & & \\
& $>50$ & 8,645 & & \\
& & & & \\
& $\mathbf{5}$ & Marital status of operators & $\mathrm{n}=60$ & \\
& Single & 24 & 0.0 & \\
& Married & 36 & 0.00 & \\
& Divorced & 0 & & \\
& Separated & 0 & & \\
\end{tabular}




\begin{tabular}{|c|c|c|c|c|}
\hline $\mathbf{S} / \mathbf{n}$ & Variable & Frequency & Percentage & Mean \\
\hline \multirow[t]{6}{*}{6} & Marital status of member-savers & $\mathrm{N}=11,982$ & & \\
\hline & Single & & & \\
\hline & Married & 2,334 & 19.48 & \\
\hline & Divorced & 9567 & 79.84 & \\
\hline & Separated & 32 & 0.27 & \\
\hline & & 49 & 0.41 & \\
\hline \multirow[t]{5}{*}{7} & Education of operators & & & \\
\hline & No formal education & 0 & 0.00 & \\
\hline & Primary education & 0 & 0.00 & \\
\hline & Secondary education & 35 & 58.4 & \\
\hline & Tertiary education & 25 & 41.7 & \\
\hline \multirow[t]{5}{*}{8} & Members savers & & & \\
\hline & Housewives & 1131 & 9.44 & \\
\hline & Traders/petty businesses & 7226 & 60.31 & \\
\hline & Public/civil servants & 1231 & 10.27 & \\
\hline & Farmers & 2394 & 19.98 & \\
\hline \multirow[t]{6}{*}{9} & Reasons for saving with DSEs & $\mathrm{n}=99.172$ & & \\
\hline & No administrative bottlenecks & $62 *$ & 62.63 & \\
\hline & Easy credit facility & $90 *$ & 90.90 & \\
\hline & $\begin{array}{l}\text { Closeness to business environment or } \\
\text { place of residence }\end{array}$ & $89 *$ & 89.90 & \\
\hline & Interest charged is low for loan amount. & & & \\
\hline & & $92 *$ & 92.93 & \\
\hline \multirow[t]{5}{*}{10} & Basis for loans supply & $\mathrm{n}=60$ & & \\
\hline & Trust & 11 & 18.33 & \\
\hline & Years of membership & 38 & 63.33 & \\
\hline & Type of business & 8 & 13.33 & \\
\hline & Client status & 3 & 5.00 & \\
\hline \multirow[t]{4}{*}{11} & Interest rate charged & $\mathrm{n}=60$ & & \\
\hline & $<5 \%$ & 20 & 33.33 & \\
\hline & $6-19 \%$ & 29 & 48.33 & $7.70 \%$ \\
\hline & $>10 \%$ & 11 & 18.33 & \\
\hline \multirow[t]{6}{*}{12} & $\begin{array}{l}\text { Number of member-savers in the DSEs } \\
<50 \text { members }\end{array}$ & & & \\
\hline & $51-100$ members & 3 & 5.00 & \\
\hline & $101-150$ members & 10 & 16.67 & \\
\hline & $151-200$ members & 9 & 15.00 & \\
\hline & $>200$ members & 8 & 13.33 & 20.7 \\
\hline & & 30 & 50.00 & \\
\hline
\end{tabular}

* - multiple responses

Source: Field data, 2019

Determinants of savings and credit extension in DSEs and implications for financial inclusion strategy

Volume of savings mobilized in a year by DSEs is influenced by the number of member-savers and the income of participants as revealed in Table 2. Four (4) forms of the functional equations were tried with the double log coming out the best in terms of significant variables and the value of coefficient of determination $\left(\mathrm{R}^{2}\right)$

The total number of member-savers was significant at 5 percent, while the income of participants was significant at 1 percent level. These significant variables are implicative for the achievement of National Financial Inclusion Strategy with regards to the savings facet. First, savers must be mobilized and majority are low income, who are essentially traders and petty business owners. Second, the significance of participants' income variable explains the fact that savings can only be build up when there is an assured income source. And for these group of participants in DSEs who engage in businesses that guarantee income almost on a daily basis even though it's not in large amount and volume, savings through this group will provide the much needed catalyst for growth. 
Table 2: Determinants of savings in Daily Savings Enterprises (DSEs)

\begin{tabular}{|c|c|c|c|c|}
\hline Variables & Linear & Semi-log & Double-log $(+)$ & Exponential \\
\hline Intercept & $\begin{array}{l}104748.175 \\
(-1.659)\end{array}$ & $\begin{array}{l}5087.016 \\
(.048)\end{array}$ & $\begin{array}{l}-640 \\
(-3898) * * *\end{array}$ & $\begin{array}{l}-460 \\
(-945)\end{array}$ \\
\hline $\begin{array}{l}\text { Number of member- } \\
\text { savers }\end{array}$ & $\begin{array}{l}-5.118 \\
(-6.666)^{* *}\end{array}$ & $\begin{array}{l}-13151.065 \\
(.15 .547)^{* *}\end{array}$ & $\begin{array}{l}-.676 \\
(-37.843) * *\end{array}$ & $\begin{array}{l}-4(3770.005 \\
(-7.391)^{* *}\end{array}$ \\
\hline $\begin{array}{l}\text { Duration of savings/ } \\
\text { month }\end{array}$ & $\begin{array}{l}3664.634 \\
(-1.8)\end{array}$ & $\begin{array}{l}-36823.187 \\
(-.029)\end{array}$ & $\begin{array}{l}.153 \\
(.171)\end{array}$ & $\begin{array}{l}.034 \\
(2.155)\end{array}$ \\
\hline Income of participants & $\begin{array}{l}0.001 \\
(6.099) * *\end{array}$ & $\begin{array}{l}14398.731 \\
(1.260)^{* *}\end{array}$ & $\begin{array}{l}1.823 \\
(35.418)^{* *}\end{array}$ & $\begin{array}{l}8.4190 .009 \\
(6.117)^{* *}\end{array}$ \\
\hline $\mathbf{R}^{2}$ & .462 & .835 & .963 & .498 \\
\hline Adjusted R ${ }^{2}$ & .433 & 8.26 & .926 & .471 \\
\hline F-value & $15.998 * * *$ & $94.567 * * *$ & $512.597 * * *$ & $18.508 * * *$ \\
\hline
\end{tabular}

Source: Calculated from field data, 2019.

Figures in parenthesis are $\mathrm{t}$-values

$+=$ lead equation

$* * *, * *, *=$ Statistically significant at $1 \%, 5 \%$ and $10 \%$, respectively

Regression result is significant at $1 \%$ level

Many member-savers with DSEs are encouraged to do so because of the prime factor of securing credit to boost their businesses. Analysis as shown in Table 3 further explains that credit extension is influenced by the number of member-savers, volume of savings in a year, interest rate charged by DSE, and volume of credit already extended. The variables were all significant at $1 \%$. The lead equation, just as in savings function is the double-log. The coefficient of determination, $\mathrm{R}^{2}$, is $99 \%$ and explains the changes in the value of credit extension arising from changes in factors that affect it, and at 99\%, indicates how well the entire regression model is. Number of member-savers significance in relation to credit extension means a lot to financial inclusion strategy. To extend reasonable credit for meaningful economic activities denotes that many Nigerians must be active savers either with the formal or informal financial institutions. Driving this objective implies targeting majority of these informal persons in small businesses whose income may be small but very key to building savings for investments. Number of savers and volume of mobilize savings are intertwined particularly when little incomes are involved. A greater number of persons are required for the savings to swell, which is why many DSEs scout for as many members as possible. A large volume of savings at any given period will mean more members getting serviced in event of seeking for credit to expand their businesses. However, volume of savings coefficient is negatively related to credit extension, implying that, as more credit is extended, the volume goes down. Interest charged on borrowed amount attracts or scares potential member-savers. The smaller the interest rate charged, the more members attracted to a particular DSE. Udoh (2005) observed that, the boom in DSEs in Nigeria is attributed to low interest charged by the operators. This, again, may explain why the participants are withdrawn from the formal financial sector and are excluded because they are more encouraged to borrow from DSEs than from formal banks. It also implies that, attracting low income persons to formal sector requires a drop in interest charged presently by many financial institutions to the same level of most DSEs or even lower. Nevertheless, it is positively related to credit extension and means that, the more the amount extended, the higher the interest amount charged. Volume of credit already extended is positively related to credit extension and against a priori expectation. It is significant all the same with implication that, credit is extended when the number of clients on serve list is not above the resources of the DSEs. 
Table 3: Determinants of credit extension in DSEs

\begin{tabular}{|c|c|c|c|c|}
\hline Variable & Linear & Semi-log & Double $\log (+)$ & Exponential \\
\hline \multirow[t]{2}{*}{ Intercept } & 20725691.981 & 1847655645 & .012 & 5.113 \\
\hline & $(.320)$ & $(.662)$ & $(.007)$ & $(.934)$ \\
\hline \multirow{2}{*}{$\begin{array}{l}\text { Number of Member- } \\
\text { savers }\end{array}$} & 44501.264 & 5769415.529 & 3.485 & .006 \\
\hline & $(5.645)^{* * *}$ & $(3.485)^{* * *}$ & $(41.325)^{* * *}$ & $(8.570)^{* * *}$ \\
\hline \multirow{2}{*}{$\begin{array}{l}\text { Duration } \\
\text { savings/month }\end{array}$} & -663561.161 & -137099299.9 & -8.162 & .012 \\
\hline & $(-.319)$ & $(-.092)$ & $(-.891)$ & $(.068)$ \\
\hline \multirow[t]{2}{*}{ Volume of savings/ year } & -126.252 & -4704744.311 & -.060 & -1.4720 .005 \\
\hline & $(-1.157)$ & $(-.221)$ & $(-.179)^{* * *}$ & $(-1.402)$ \\
\hline \multirow[t]{2}{*}{ Interest amount charged } & -67364.691 & 207683.328 & .068 & .009 \\
\hline & $(-1.007)$ & $(.009)$ & $(.739) * * *$ & $(1.518)$ \\
\hline \multirow{2}{*}{$\begin{array}{l}\text { Volume of credit } \\
\text { already extended }\end{array}$} & 40.428 & 7053814.910 & 10.583 & 5.0280 .006 \\
\hline & $(4.554)^{* * *}$ & $(.447)^{* * *}$ & $(35.614)^{* * *}$ & $(6.414)^{* * *}$ \\
\hline $\mathbf{R}^{2}$ & .594 & .560 & .990 & .798 \\
\hline Adjusted $\mathbf{R}^{2}$ & .556 & .489 & .989 & .771 \\
\hline F-value & $15.706 * * *$ & $7.900 * * *$ & $643.436 * * *$ & $30.025 * * *$ \\
\hline
\end{tabular}

Source: Field data analysis, 2019

Figures in parenthesis are t-values

$* * *=$ significant at $1 \%$

$+=$ lead equation

Regression result is significant at $1 \%$ level

Volume of credit extended in the last one

As at 2019, when the study was conducted, the operators of the DSEs had extended average credit of 332,083 $(\$ 1,509.47)$ from 2018 to 2019 . As shown in Table 4, majority of these DSEs $(26.67 \%)$ extended credit volume of between 301,000 - 400,000. The volume of credit extended may not be large but it's instructive. First, it helps the participants to solve personal and business related problems. Second, it helps very many of them to build their businesses up and by so doing, expand investment and the economy. On the other hand, the volume of savings is small and demand from participants is large and therefore, if all must be serviced, amount of credit extended to all participants will be small.

Table 4: Volume of credit extended to clients

\begin{tabular}{lllll}
\hline S/no & Volume of credit & $\begin{array}{l}\text { Frequency } \\
(\mathbf{n = 6 0 )}\end{array}$ & Percentage & Mean \\
\hline $\mathbf{1}$ & $1,000-100,000$ & 5 & 8.33 & 332083 \\
\hline $\mathbf{2}$ & $101,000-200,000$ & 4 & 6.66 & \\
\hline $\mathbf{3}$ & $201,000-300,000$ & 10 & 16.70 & \\
\hline $\mathbf{4}$ & $301,000-400,000$ & 16 & 26.70 & \\
\hline $\mathbf{5}$ & $401,000-500,000$ & 1 & 1.67 & \\
\hline $\mathbf{6}$ & $501,000-6000$ & 4 & 6.66 & \\
\hline $\mathbf{7}$ & $>600,000$ & 10 & 16.70 & \\
\hline
\end{tabular}

Source: Field data analysis, 2019.

Challenges in DSEs operations and possible means of overcoming them

A checklist of possible challenges faced by DSEs as raised by some studies was presented to the operators with some adjustments. The challenges ranged from trust issues, mobility to clients' business environment, taxation, harassment/abuse from clients and government officials as well as inflation and swings in the general economy. Table 5 shows that many of the operators obviously, mobilize savings far from where they lived as movement to where clients were was a major challenge $(41.7 \%)$. Aside this, they faced harassment and abuse from clients and others $(28.3 \%)$; were not fully trusted by some clients $(15 \%)$; could move miles and not mobilize much because of downturn in the economy or announcement of some policy swing, particularly change in petroleum product prices $(15 \%)$. The challenges affected operators' operations but still never deterred DSEs from springing up. Nevertheless, these challenges are not insurmountable if DSEs

are properly harnessed and incorporated into the National Financial Inclusion Strategic Plan.

For swings in the economy, it is as a result of some shocks which may be controlled by a larger economic plan. Trust issues may arise when clients are not very sure of a specific location of an operator.

To overcome this, operators must have some business base to operate from, just like what happens with conventional banks- an office of sort. Again, if the operators are properly identified and registered with necessary governmental bodies, harassment and abuse will be curtailed. If banks can use operators' services and 
draft them in accordingly, mobility can be taken care of by providing vehicles for such movements. Table 5: Challenges faced by operators of Daily Savings Enterprises

\begin{tabular}{|l|l|l|l|}
\hline s/no & Challenges faced by operators & $\begin{array}{l}\text { Frequency } \\
\mathrm{n}=60\end{array}$ & Percentage \\
\hline 1 & Trust issues & 9 & 15 \\
\hline 2 & Distance to clients location & 25 & 41.7 \\
\hline 3 & Taxation & 0 & 0 \\
\hline 4 & Harassment/abuse & 17 & 28.3 \\
\hline 5 & General Economic fluctuation & 9 & 15 \\
\hline
\end{tabular}

Source: Field data, 2019

\section{Conclusion}

Nigeria's economy needs some revamping and a re-direction as well as re-orientation away from crude oil. Investments into other sectors will come from accumulated savings from formal and informal financial institutions. These savings are mobilize from the citizens. Many citizens will, however, not save with some financial institutions if the conditions are cumbersome. Many Nigerians are of the notion that flexibility and simplicity should be the hallmark of any financial scheme. Nigerians in rural areas will definitely find it stressful to come out to urban centers to save with financial institutions if they are not located in their environment and their conditions are not favorable. To them, saving with people around them is much easier and better. DSEs provide most of these rural dwellers and many urban low income groups with the needed succor and financial freedom because savings are less troublesome and loans granted are mostly quick maturing, very accessible, selfproliferating, profusely spread and flexibly rescheduled. If DSEs are effectively mainstream into the National Financial Inclusion Plan, these savings from rural dwellers and urban low income groups, can be mop-up for the much needed Investments

\section{Acknowledgments}

The authors are grateful to the operators and participants of DSEs for the data provided and the time spent in the interview sessions. We are equally indebted to our senior colleagues in the department of agricultural economics particularly Prof E. O Eyo for his very insightful comments. To our students and the extension agents who help in administering the instrument of data collection, we thank you so much for your efforts. Finally, we bear the responsibility of errors contain in the work and also wish to state that the views expressed in the article are entirely ours.

\section{References}

Adams, D. W. \& Vogel, R. C. (1986)." Rural financial market in low income countries: Recent controversies and lessons". World Development, 14(4), 477-487.

Adeyemo, R. \& Bamire, A. S. (2005). "Saving and investment pattern of cooperative farmer in south western Nigeria". Journal of Social Sciences, 11(3), 183-192.

Adjei, J. K., Arun, T. \& Hossain F. (2009). "The role of microfinance in asset building and poverty reduction: the case of Sinapi Aba Trust of Ghana". BWPI Working Paper 87; University of Manchester

Akanji, O. O. (2010). Policy issues in informal financial sector development. Central Bank of Nigeria bulletin 22(3): 20-27.

Akin-Fadeyi, T. \& Prochazka, J. (2016). "Financial inclusion in Nigeria: trends, achievements, challenges and prospects". Bullion. A publication of the Central Bank of Nigeria. Vol 1-40.

Berger, A. N. \& Udell, G. F. (2004). "A more complete conceptual framework for SME finance. World Bank conference on small and medium enterprises: Overcoming growth constraints". World Bank, MC -13-121. October 14-15, 2004.

Berger, A. N. \& Udell, G. F. (2006). “A more complete conceptual framework for SME finance”. Journal of Banking and Finance. 30(11), 2945 - 2966.

Bime, M. W. (2007). "Savings mobilization and rural credit market performance in the North West province of Cameroon". Unpublished Ph.D thesis, University of Calabar, Nigeria.

Eboh, E. C. (2000). "Rural informal savings and association as risk managers and the lessons for the design and execution of rural credit schemes in Nigeria”. Journal of African Development Review. 12(2), 233-261.

Enhancing Financial Innovation and Access (EEInA) (2010). EfinA Access to financial services in Nigeria 2010 survey: key findings

Graham, U. E. (1992). "Assessment of the performance of Nigeria's rural financial institutions". Central Bank of Nigeria (CBN) Monograph series, 1(2), 101- 125.

Idowu, A.O., Ambali, O. I., Otunaiya, A. O., \& Sanni, O. I (2011). "Determinants of small scale pig business financing in Egbeda local government area of Oyo State, Nigeria". Proceedings of NAAE'11 Conference, 


\section{7-243.}

Iganiga, B. O. \& Asemota, A. (2008). "The Nigerian unorganized financial institutions and operations: A framework for improved rural credit schemes in a fragile environment". Journal of Social Sciencces, 17(1), $63-71$.

Iganiga, B. O. (2000). "The structure of the Nigerian financial system". Ibadan - Nigeria. Amfidom publishers. Ijere, M. O. (1986). "New Perspective in financing Nigeria Agriculture". Fourth Dimension Publishers, Nigeria. Ike, P. C. \& Idoge, D. E. (2006). "Determinants of financial savings among rural households in Delta state, Nigeria". Journal of Applied Chemistry and Agricultural Research, 2(9), 95-107.

Isong, O. (2010). External financing for agricultural development in Nigeria: A paper presented at Central bank of Nigeria (CBN) Seminar for senior staff. Lagos, April 29-30.

Mejaha, R. O., Iheke, O. R. \& Afonne, G. (2007). "Effect of microfinance service on savings, investments and output in Abia State of Nigeria". Pakistan Journal of Social Sciences, 4(4), 559-564

National Bureau of Statistic (NBS) (2018): Annual Statistical Abstract. 